\title{
Shared Governance At Lincoln University: An Elusive Quarry
}

\author{
James L. DeBoy, Lincoln University of PA, USA
}

\begin{abstract}
This paper identifies those factors that led to American Association of University Professors (AAUP) representation at the nation's oldest degree-granting Historically Black College University (HBCU). In the span of 18 months, Lincoln Faculty overwhelmingly embraced unionism when the body agreed to have AAUP as its official agent in the collective bargaining process. While the decision to organize presented some difficulties, securing and maintaining faculty voice in campus decision-making was fraught with challenges. That struggle continues today.
\end{abstract}

Keywords: Higher Education; Shared Governance; Corporatization; Faculty Unionization

\section{INTRODUCTION}

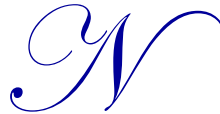

ot unlike many other institutions of higher education, Lincoln University Faculty have experienced highs and lows with regard to participatory decision-making in the educational enterprise. What appears to distinguish Lincoln from their counterparts, however, is that these fluctuations in shared governance have been incredibly pronounced over some four decades. This paper will chronicle those events that culminated in the Faculty's decision to "organize" at the nation's first degree-granting Historically Black College/University (HBCU). As we shall see, securing collective bargaining on campus would prove to be far easier than regaining and sustaining an effective faculty voice in campus decision-making. That struggle continues today.

\section{Overview of Lincoln University (PA)}

Founded in 1854, Lincoln University is the oldest college in the nation having as its original purpose the highest education of students "of every clime and complexion" (Lincoln University Bulletin 1982-84). Embracing the classical conception of a university, Lincoln has historically formally recognized the primacy of the university's three purposes: (1) teach honestly without fear of censure; (2) preserve knowledge for the future; and (3) add to the store of knowledge (Lincoln University Bulletin 1995-1998). It bears mentioning that the Lincoln culture was largely influenced by the first faculty cohort who, almost to a man, received his degree (undergraduate and/or graduate) from Princeton University. Without question, this Princeton connection left an indelible imprint upon the faculty who were to follow. Consequently, Lincoln University was often referred to as the "Black Princeton" - a tribute to its founding faculty.

\section{Princetonian Culture}

A university may be characterized as a community of scholars/learners engaged in discussion, disagreement, argumentation, debate, skepticism and criticism of ideas. Perhaps, Marvin Wachman's presidency (1961-70) best captured such a mindset whereby President Wachman championed human rights and equality of opportunity. In retrospect of his six decades of university service, Wachman noted that our nation's best college presidents had been former professors and scholars and that such training enabled them to fully understand, appreciate, and embrace the university culture (Wachman, 2005). That "culture" welcomed challenges, encouraged questioning, and expected reasoned justifications for policies and practices. A staunch advocate of freedom of expression, Wachman (2005) adamantly supported those cherished pillars of higher education: academic freedom and shared governance. Monthly Faculty meetings, led by Dr. Wachman, lasted some three hours - not determined 
so much by length of the agendas but due to the lively, participatory discourse among faculty discussants (R.C. Winchester, personal communication, February 21, 2015). While faculty and President Wachman did not agree upon all issues, both parties were kindred spirits in the sense that disagreement was perceived as a natural, necessary means for advancing ideas and ultimately, the institution. In the end, the most convincing argument should hold sway in most important matters. Not surprisingly, this intellectual reckoning also was much in evidence in the late 1960s classroom: "The seminars at Lincoln were slam-bang affairs with unfettered give and take." (Farmer, 1998, p. 307). It bears mentioning that wider society in this time period had adopted a similar skeptical, critical disposition toward its social institutions, e.g., government, military, religion. Sadly, the next Lincoln era (1970-85) would witness a merciless assault upon this quintessential bastion of liberal intellectual traditions.

\section{Governance Proposal (1969-71)}

While the interaction style and lines of communication between Lincoln Faculty and administration may have been characterized as "open" and "egalitarian", the University's governance structures were perceived by many as more oppressive than progressive. Both administration and Faculty recognized these shortcomings and, by the end of the 60s decade, the University secured a Ford Foundation grant for the purposes of reviewing the existing governance structure and recommending changes that would produce "a harmonious and effective vehicle for establishing and implementing policy" (Winchester, 1971). Without question, the 1960s brought significant change to our nation's colleges - Lincoln was no exception as evidenced by increased student and faculty populations (200 percent and 300 percent respectively), residential co-education, a host of new buildings, and dramatic growth of supportive services (clerical, maintenance, secretarial, medical-psychological, audio-visual, and student placement).

The Governance Proposal for Lincoln University (Winchester, 1971) reaffirmed Faculty and administration misgivings about its present governance structure: it was antiquated both in terms of current thinking/trends and, more importantly, by-passed Faculty standing committees by developing a rash of ad hoc committees that created the impression of informal, improvisational decision-making. Given these findings, the Governance Committee sought to "reform the university's structure, not simply redefine university policy" (Winchester, 1971). Subsequently, Committee leadership, in its attempt to democratize decision-making, expanded its role to address both governance and grievance matters. The Committee's recommendations emphasized transparency and participatory decision-making; as envisioned by the Governance Committee, governance at Lincoln University would be both a right and a responsibility for all members of the campus community. However, the person occupying the President's Office (1970-1985) did not share such a conviction; indeed, an overwhelming majority of Lincoln faculty would conclude his actions eschewed the libertarian position.

\section{Paradise Lost}

With the arrival of a new University President in July 1970 -- a president whose leadership style would sharply contrast with that of his predecessor (M. Wachman) -- a collision course was set given the Faculty's agenda of organizational reform as outlined in the Governance Report. Lincoln Faculty's predilection for speaking up-andout would soon be interpreted by Herman R. Branson as impudent effrontery. Dr. Branson, a product of Southern HBCU academe culture, perceived his main job as "keeping the lid on" (Phillips, 2002) Lincoln faculty and students lest they incur the wrath of external stakeholders. It has been argued that Southern HBCUs enjoyed/endured a precarious existence... operating on the goodwill of some powerful, white policymakers; unsettling this group was equated with the dissolution of the HBCU experiment. To be fair, there are legitimate claims posited by HBCU proponents that strong, i.e., autocratic, leadership was responsible (and, indeed, required) for the survival and progress of some Black campuses (Minor, 2005). Not surprisingly, Lincoln faculty rejected such an argument... at least for this Northern HBCU campus. 
Specifically, a series of presidential proclamations/unilateral decisions galvanized the Lincoln faculty in their outright resistance to Branson's presidency:

- $\quad$ Rejection of Governance Report

- Creation of ad hoc committees to circumvent faculty-elected standing committees

- $\quad$ Dismissal of faculty without due process procedures being followed

- Low correlation between faculty-recommended candidates for promotion/tenure and presidential/Trustee approvals

- Violations of shared governance

- Violations of Faculty By-Laws

- $\quad$ Curtailment of freedom of speech

- $\quad$ Blatant (selective) disregard for Roberts Rules of Order when chairing faculty meetings

- Curtailment of criticisms of administration

- Dictatorial and oppressive mode of "communicating"

- $\quad$ Misleading academic community as to discussions/decisions that occurred at State level

- $\quad$ Advocating "gag order" that barred Trustee-faculty interactions

After just 18 months of the Branson presidency (1972), the Lincoln faculty voted in the American Association of University Professors (AAUP) to represent them in collective bargaining with the Lincoln University administration. The final vote was 78-6 in favor of unionization. The numbers speak for themselves: Lincoln faculty aspirations for shared decision-making in the nation's oldest degree-granting institution would not be dampened. Faculty activism would not be quelled. Faculty governance would not devolve into faculty audience. Lincoln faculty are not passive, disengaged, nor fearful. Lincoln faculty will expend time, energy and effort in transforming Lincoln's "president-centric" culture (Sheftall, 2006) towards a model that cherishes shared governance, academic freedom, and critical feedback. That very stance would lead to some 20 filed grievances (including the notice of termination sent to all 100 faculty), a few university-wide shutdowns, a host of heated harangues, abruptly-ended faculty meetings, countless ad hominem attacks (hurled from and toward the presidential lectern), two faculty arrests, and a two week strike occurring during the remaining 13 years of President Branson's reign. Freedom, including its pursuit, does have its associated costs.

\section{Timing is Everything}

Had the Lincoln faculty vote for union representation occurred five years earlier (1967), AAUP representation would not have been available (Benjamin, 2015). Historically, AAUP leadership had utter disdain for "unionism" tactics, e.g., withholding of services, strikes, contract bargaining, and legislative lobbying ; negotiating with administrators over freedom rights (academic freedom, tenure) superseded any efforts disparagingly perceived as self-advertisement (Metzger, 1965). Its founding fathers (John Dewey and Arthur Lovejoy -- 1915) envisioned (and operated) AAUP as a professional organization of scholars (aristocrats of academe) committed to the advancement of higher education but intentionally separating Association activities and functions from anything to do with material/financial gain - AAUP principles were designed, in part, to distance itself from "trade unionism" (Hofstadter \& Metzger, 1955). The dignity of the professoriate, based upon a genteel code of manners, was inherently incompatible with any pressure-laden strategy. Such a mindset prevailed until the late 1960s. This era witnessed a significant interest in faculty bargaining by AAUP counterparts, the American Federation of Teachers (AFT) and the National Education Association (NEA) given state-enabling legislation fueling such interest (Benjamin, 2015). Collective bargaining, though not officially voted in until the annual meeting in June 1972, had been secured in 1970 for Rutgers University, St. John's University, and Oakland University as the first three AAUPrepresented university faculties (Benjamin, 2015). Two years later Lincoln University would join the ranks of the founding three members, three more in 1971, and the seven others who enjoined AAUP-representation in 1972. By 1975, AAUP would represent 35 colleges. Without question, the AAUP in the span of 55 years had experienced a paradigm shift - from an association of academic elites to an organization of political and economic change agency. Lincoln, and its 13 fledgling co-representative institutions, would avail themselves of AAUP's resources and support in the coming years. 


\section{Challenges Remain}

Initially insidious but blatantly overt today, the corporatization of higher education poses perhaps the most serious threat to faculty governance in our nation's history (Chomsky, 2014; Nelson, 2010; Gerber, 2009; Phillips, 2002). The fundamental goal of this business model is to reduce labor costs and to ensure a docile, servile labor force (Chomsky, 2014). The methodology for achieving these goals is to instill worker insecurity via elimination of faculty tenure with a corresponding proliferation of adjunct/contingent instructors - cheap, vulnerable, exploited labor. When faculty are marginalized, they are less likely to "cause problems", i.e., become politically engaged and seek rights. Employment instability is likely to engender passivity and apathy. A second component of corporatization is layer after layer of professional managers that are highly-paid and whose function is to control and dominate (Ginsberg, 2011). In the past 40 years faculty and student populations have remained proportionately similar; however, the ratio of college administrators and support staff has far exceeded those of faculty and students (Chomsky, 2014). The aforementioned description of the corporate take-over of academe parallels the management techniques found in the factory: labor is expected to be obedient, quiet, and subservient to management... an unsettling resemblance to diminished faculty voice aka unshared faculty governance. For a more detailed response to this eroding force of corporatization, see When the corporate storm strikes the academy: Faculty response required (DeBoy, 2015).

\section{Benefits of Faculty Governance}

Effective shared governance is more than simply faculty participation - the focus should be on how such participation advances the institution (Minor, 2005). Advancement of any organization is best served by collaboration among its many constituencies (Legon, 2014). Effective shared governance links the university president, faculty, and board in a productive partnership (Bahls, 2014). Effective shared governance is a necessary variable for any educational system to thrive (Gasman \& Hilton, 2010). Effective shared governance is open communication. Effective shared governance creates and sustains freedom of expression, critical thinking, challenge, and honest feedback - attitudes and actions that strengthen both individuals and institutions. Unless our nation's colleges and universities emulate such cooperative ventures in institutional decision-making, maximum advancement will be thwarted. Effective shared governance increases the likelihood that expertise, education, and experience of faculty stakeholders are effectively utilized so that institutional advancement is assured.

\section{CONCLUSION}

Given the relatively short, seven year tenure of American colleges' top administrators (Cook \& Kim, 2012), faculty are better positioned to provide the institutional memory that guides institutional planning. Faculty voice, bolstered with institutional memory, is less likely to repeat past failures. Genuine shared governance dilutes absolute power and control in one (executive) level of the institution thereby lessening the possibility of creating a distorted perspective of the academic enterprise (AFT, 2004). Shared governance (democracy in action) is the epicenter of academic freedom and professional autonomy. Erosion of faculty input paves the way for political, commercial, and/or short-term managerial usurpation of the academy. Our students, our nation deserve better.

\section{ACKNOWLEDGEMENTS}

My thanks to Richard C. Winchester, Professor Emeritus (Lincoln University 1961-2000), for his unwavering commitment to faculty governance, passionate love of history, embodiment of Lincoln's institutional memory and the willingness to share those experiences and insights.

\section{AUTHOR INFORMATION}

James L. DeBoy earned a PhD in Human Development (with minor concentrations in Special Education and History of Education) at the University of Delaware. He was appointed to the Lincoln University faculty in 1975 and achieved rank of Professor in 2000. A department chair for 22 years, he served on virtually all major academic committees, assumed a lead role in outcomes assessment for 20 years, assisted in his university's re-accreditation process for 30 years, acted as Faculty Contract Administrator the past four years, negotiated numerous Faculty- 
University contracts for his local AAUP chapter of which he has been a member for 40 years. Teaching in the Department of Nursing \& Health Sciences, Dr. DeBoy has presented papers at regional, national, and international conferences on such diverse topics as psychomotor development, human cognition/metacognition, substance abuse prevention, obesity screening, outcomes assessment of student learning, and corporatization of higher education. Email: luhper1111@,aol.com

\section{REFERENCES}

American Federation of Teachers (2004, June). Shared governance in colleges and universities. A Statement by the Higher Education Program and Policy Council, Item no. 36-0696. Washington, DC.

Bahls, S.C. (2014, March/April). How to make shared governance work: Some best practices. Trusteeship, 22 (2), 30-34.

Benjamin, E. (2015, January/February). How did we get here? Academe, 101 (1), 38-45.

Chomsky, N. (2014, February). Chomsky: How America's great university system is being destroyed.

Alternet. Retrieved from: http://www.alternet.org/corporate-accountability-and-workplace/chomsky

Cook, B. , \& Kim, Y. (2012). The American college president 2012. American Council on Education.

DeBoy, J.L. (2015). When the corporate storm strikes the academy: Faculty response required. Contemporary Issues in Education Research, 8 (1), 15-18.

Farmer, J.B. (1998). Lay bare the heart: An autobiography of the civil rights movement. Fort Worth, TX: TCU Press.

Gasman, M., \& Hilton, A.A. (2010). A 25-year history of the American Association of University Professors perspective on shared governance at Historically Black Colleges and Universities. Journal of Research in Education, 20 (1), 53-60.

Gerber, L.G. (2015, January/February). College and university governance. Academe, 101 (1), 31-37.

Gerber, L.G. (2009, November/December). Governance in a time if financial crisis. Academe, 95 (6), 2.

Ginsberg, B. (2011). The fall of the faculty: The rise of the all—administrative university and why it matters. Oxford University Press.

Hofstadter, R., \& Metzger, W.P. (1955). The development of academic freedom in the United States.

New York: Columbia University Press.

Legon, R. (2014, March/April). The 10 habits of highly effective boards. Trusteeship, 22 (2), 8-13.

Lincoln University Bulletin 1982-84, Lincoln University (Pa.).

Lincoln University Bulletin 1995-98, Lincoln University (Pa.).

Metzger, W.P. (1965, Summer). Origins of the association. AAUP Bulletin, 51 (3), 229-237.

Minor, J.T. (2005). Faculty governance at Historically Black Colleges and Universities. Academe, 91 (3), 34-37.

Nelson, C. (2010). No university is an island: Saving academic freedom. New York: NY University Press.

Phillips, I.P. (2002). Shared governance on black college campuses. Academe, 88 (4), 50-55.

Wachman, M. (2005). The education of a university president. Philadelphia: Temple University Press.

Winchester, R.C., \& Lincoln University (Pa.) Governance Committee. (1971). A governance proposal for Lincoln University. [Lincoln University, Pa.]. 


\section{NOTES}

